\title{
Exploring Students' Decision-Making Ability in the Context of Socio-Scientific Issues
}

\author{
Dita Ardwiyanti ${ }^{1, *}$ Zuhdan Kun Prasetyo ${ }^{2}$ \\ ${ }^{1}$ Master of Natural Science Education, Faculty of Mathematics and Natural Sciences, Universitas Negeri \\ Yogyakarta, Indonesia \\ ${ }^{2}$ Department of Natural Science Education, Faculty of Mathematics and Natural Sciences, Universitas Negeri \\ Yogyakarta, Indonesia \\ *Corresponding author. Email: ditaardwiyanti.2019@student.uny.ac.id
}

\begin{abstract}
Decision-making is a vital competence for a participatory living in 21 st-century societies, which is plausible to prompt sustainable development goals. The purpose of the present study was to describe students' decision-making ability in the socio-scientific context focusing on three aspects: stating the option, describing the decision-making strategy, weighing the criteria according to personal values. This survey study involved 160 junior high school students through a simple random sampling technique. Data were collected using an open-ended questionnaire in the context of the future of grouper fish's issue. Data were analyzed quantitatively using percentage calculation and qualitatively based on excerpts of students' responses. The results showed a disparity in the students' decisionmaking abilities in each aspect. The ability to state the option was mostly high-developed. However, most students found difficulties describing the decision-making strategy and weighing the criteria according to personal values. These findings urge the science education researcher to innovate the most appropriate decision-making-oriented learning.
\end{abstract}

Keywords: Decision-making, Science education, Socio-scientific issues

\section{INTRODUCTION}

Indonesia is facing global issues that challenge national development. Despite the Government's significant progress report, the prevalence of stunting and wasting, the threat of food insecurity, pollution, deforestation, and income inequality are still headlining the Indonesian news media. These issues essentially reflect the imbalance between humanity and the planet, which is the main problem that the world wants to resolve through the universal agreement of the 17 sustainable development goals (SDGs) and 169 targets.

In the roadmap of SDGs Indonesia [1], the Government describes and highlights some key issues prioritized for immediate resolution: health, education, social protection, food security and sustainable agriculture, infrastructure, ecosystem services and biodiversity, and also the financing for Government's administration. Innovative approaches and strategies are needed to achieve ambitious goals, considering the extensive coverage of the issues.
Education is the foundation of the other target in realizing the SDGs. The study of the Institute for Global Environmental Strategies (IGES) revealed this linkage [2]. The analysis showed that 17 high driver power targets out of 9 goals affect other targets with a low dependency level. The two targets at the lowest level, all for free primary \& secondary education and double energy efficiency, can be interpreted as the main levers in achieving many other SDGs targets. Education is needed to build literacy to support all SDGs goals that try to balance the economic, social, and environmental aspects [3].

Education, particularly science education, should transform students into scientifically literate citizens by equipping them with the capability to decide and perform sustainable action on socio-scientific issues (SSI) in daily life [4]. Decision-making can be manifested within the education for sustainable development (ESD) framework as a process to interpret socio-scientific knowledge into informed decisions, leading to the chosen action in the realworld [5]. Therefore, decision-making can be 
established as a vital competence for a participatory living in the democratic and pluralistic of the $21 \mathrm{st}-$ century societies [6,7], which prompts SDGs' accomplishment.

Decision-making refers to the process of selecting the best option among several available alternatives [8]. This process cannot take place intuitively. It requires evaluating possible actions ethically associated with multiple criteria/attributes in the context of SSI $[9,6]$. The trade-offs process, weighing each option's advantages and disadvantages by specific criteria/attributes based on scientific knowledge and personal values, is the core of the decision-making process $[10,11]$.

There are two decision-making strategies based on behavioral decision research: compensatory \& noncompensatory $[12,9,6]$. A benefit on one attribute may compensate for a drawback on another attribute through a systematic way of trade-offs in compensatory strategy. In contrast, the noncompensatory strategy does not allow trade-offs among criteria. Thus, the compensatory rule, or the optimization strategy, is the most suitable strategy for educational purposes [13].

The profile of Indonesian students' decisionmaking has not been disclosed in depth. However, this description is needed by education practitioners to determine appropriate development strategies in science classroom discourse. Regarding the rationalization, the present study aims to describe students' decision-making ability in the context of SSI based on three aspects: stating the option, describing the decision-making strategy, weighing the criteria according to personal values. The issue of the future of grouper fish (Epinephelus sp.) is used as the assessment context considering this issue meets the SSI criteria that are dilemmatic (involving moral and ethical considerations), contextual, and require multiperspectives solutions [14,15]. Within this SSI, students' attitudes and actions towards the biodiversity crisis as one of Indonesia's SDG's most prioritized issues can be disclosed.

\section{RESEARCH METHODS}

This descriptive study used a survey method to describe students' decision-making abilities in the SSI context. A total of 160 junior high school students in Yogyakarta Province were taken as samples randomly. Decision-making ability was assessed using an openended questionnaire adapted from Eggert and Bögeholz [10]. The adapted instrument has met the content validity requirements based on expert judgment, a Science Education Professor, through a focus group discussion. Data were analyzed quantitatively and qualitatively based on the decisionmaking rubric that focused on three aspects: stating the option, describing the decision-making strategy, weighing the criteria according to personal values $[10,6,16]$, presented in Table 1 . The students' decisionmaking abilities were then classified into three levels for each aspect.

\section{RESULTS AND DISCUSSION}

The description of students' decision-making abilities in each aspect is shown in Table 2. In stating the option, most students managed to reach level 3 with a percentage of $66.25 \%$. The findings differed in two other aspects revealed by this survey. Mastery of describing the decision-making strategy was mostly still at level 2, with $49.38 \%$. Meanwhile, on weighing the criteria according to personal values, most students could only achieve level 1 with a percentage of $96.25 \%$.

This study also serves to analyze the qualitative pattern of students' decision-making abilities. The excerpt of students' responses to each aspect of decision-making is presented in Table 3. It will be discussed in the section below.

In the present study, students were asked to decide on the best action to conserve groupers whose population is decreasing due to overexploitation. Three alternative solutions are being offered: increasing the size of the mesh (action 1); stopping fishing for three years (action 2); creating marine protected areas (action 3). Students' responses contain the chosen action and justification. These responses describe the decision-making ability in the context of SSI in three aspects: stating the option, describing the decision-making strategy, and weighing the criteria according to personal values. 
Table 1. The scoring rubric of the decision-making questionnaire

\begin{tabular}{|c|c|c|c|}
\hline Aspect Description & $\begin{array}{c}\text { Level } 1 \\
\text { (low-developed) }\end{array}$ & $\begin{array}{c}\text { Level } 2 \\
\text { (moderate-developed) }\end{array}$ & $\begin{array}{c}\text { Level } 3 \\
\text { (high-developed) }\end{array}$ \\
\hline Stating the option & $\begin{array}{l}\text { State the option without } \\
\text { rational consideration }\end{array}$ & $\begin{array}{l}\text { State the option with } \\
\text { irrational consideration }\end{array}$ & $\begin{array}{l}\text { State the option with } \\
\text { rational consideration }\end{array}$ \\
\hline $\begin{array}{l}\text { Describing the } \\
\text { decision-making } \\
\text { strategy }\end{array}$ & $\begin{array}{l}\text { Does not describe the } \\
\text { decision-making strategy }\end{array}$ & $\begin{array}{l}\text { Describe the non- } \\
\text { compensatory } \\
\text { decision-making } \\
\text { strategy }\end{array}$ & $\begin{array}{l}\text { Describe the } \\
\text { compensatory } \\
\text { decision-making } \\
\text { strategy }\end{array}$ \\
\hline $\begin{array}{l}\text { Weighing the criteria } \\
\text { according to } \\
\text { personal values }\end{array}$ & $\begin{array}{l}\text { Not weighing the criteria } \\
\text { according to personal } \\
\text { values }\end{array}$ & $\begin{array}{l}\text { Weighing the criteria } \\
\text { according to personal } \\
\text { values implicitly }\end{array}$ & $\begin{array}{l}\text { Weighing the criteria } \\
\text { according to personal } \\
\text { values explicitly }\end{array}$ \\
\hline
\end{tabular}

Table 2. The profile of students' decision-making abilities

\begin{tabular}{|c|c|c|c|}
\hline \multirow[b]{2}{*}{ The Achievement Levels } & \multicolumn{3}{|c|}{ Decision-Making Aspects } \\
\hline & $\begin{array}{l}\text { Stating the Option } \\
\text { (\%) }\end{array}$ & $\begin{array}{l}\text { Describing the } \\
\text { Decision-Making } \\
\text { Strategy (\%) }\end{array}$ & $\begin{array}{l}\text { Weighing the Criteria } \\
\text { According to } \\
\text { Personal Values (\%) }\end{array}$ \\
\hline Level 3 (high-developed) & 66.25 & 40.62 & 3.75 \\
\hline $\begin{array}{l}\text { Level } 2 \text { (moderate- } \\
\text { developed) }\end{array}$ & 20.62 & 49.38 & 0.00 \\
\hline Level 1 (low-developed) & 13.13 & 10.00 & 96.5 \\
\hline
\end{tabular}

\subsection{Stating the Option}

The results showed that most of the students' abilities to state the option were high-developed (level $3)$. It means that students at level 3 can state their option along with the reasonable consideration of its advantages and/or disadvantages. For instance, Respondent 49 (level 3) chose action 3, accompanied by logical considerations regarding environmental conservation and economic opportunity. The reasonable consideration obtained through the scientific reasoning process is essential in the decision-making process because this process cannot be done spontaneously [10].

Table 3. The excerpt of students' responses

\begin{tabular}{|c|c|c|c|}
\hline \multirow{2}{*}{$\begin{array}{c}\text { The } \\
\text { Achievement } \\
\text { Levels }\end{array}$} & \multicolumn{3}{|c|}{ Decision-Making Aspects } \\
\hline & Stating the Option & $\begin{array}{c}\text { Describing the Decision- } \\
\text { Making Strategy }\end{array}$ & $\begin{array}{c}\text { Weighing the Criteria } \\
\text { According to Personal } \\
\text { Values }\end{array}$ \\
\hline $\begin{array}{l}\text { Level } 3 \text { (high- } \\
\text { developed) }\end{array}$ & $\begin{array}{l}\text { I choose action 3. Although } \\
\text { the number of groupers } \\
\text { shortly is low, the fish will } \\
\text { increase after a few years. } \\
\text { Job opportunities in the } \\
\text { future are also guaranteed }\end{array}$ & $\begin{array}{l}\text { Action 3. Although the } \\
\text { number of groupers } \\
\text { available in the market is } \\
\text { small, at least. . . } \\
\text { employment opportunities }\end{array}$ & $\begin{array}{l}\text { My priority is the } \\
\text { maintenance of the grouper } \\
\text { population, ensuring the } \\
\text { opportunity to work in the } \\
\text { fishing industry, and } \\
\text { grouper fish availability. I }\end{array}$ \\
\hline
\end{tabular}




\begin{tabular}{|c|c|c|c|}
\hline \multirow{2}{*}{$\begin{array}{l}\text { The } \\
\text { Achievement } \\
\text { Levels }\end{array}$} & \multicolumn{3}{|c|}{ Decision-Making Aspects } \\
\hline & Stating the Option & $\begin{array}{c}\text { Describing the Decision- } \\
\text { Making Strategy }\end{array}$ & $\begin{array}{c}\text { Weighing the Criteria } \\
\text { According to Personal } \\
\text { Values }\end{array}$ \\
\hline & $\begin{array}{l}\text { so that it can reduce the } \\
\text { unemployment rate. } \\
\text { (Respondent 49) }\end{array}$ & 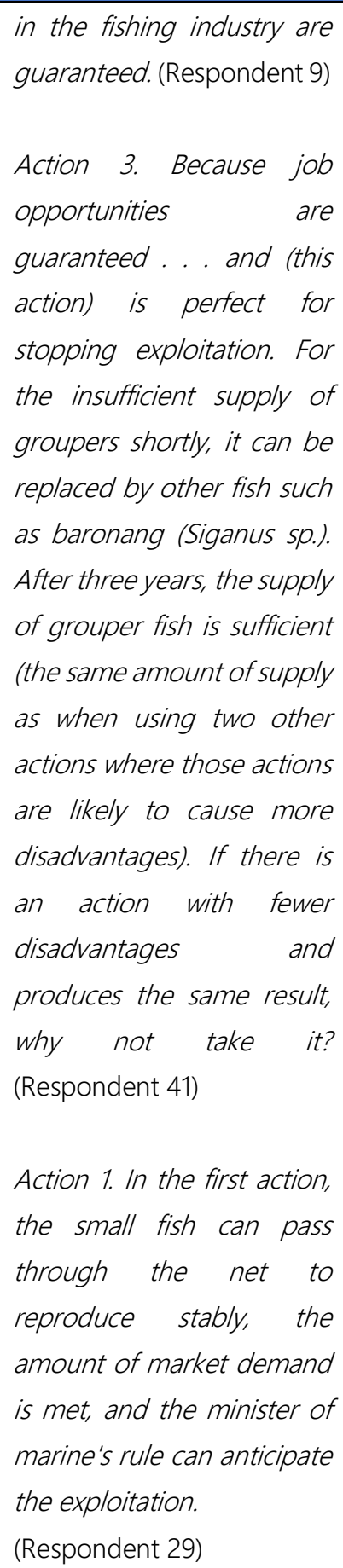 & $\begin{array}{l}\text { choose action } 3 \text { by } \\
\text { prioritizing grouper } \\
\text { populations.... } \\
\text { (Respondent 19) } \\
\text { I choose action } 3 \text { because it } \\
\text { is the most balanced of all: } \\
\text { not eliminating the sale of } \\
\text { groupers, not exploiting } \\
\text { groupers, and also } \\
\text { guaranteed employment } \\
\text { opportunities.... } \\
\text { (Respondent 85) }\end{array}$ \\
\hline $\begin{array}{l}\text { Level } 2 \\
\text { (moderate- } \\
\text { developed) }\end{array}$ & $\begin{array}{l}\text { Action 3, protect the } \\
\text { marine environment. } \\
\text { (Respondent 82) }\end{array}$ & $\begin{array}{l}\text { Action 3, so that grouper } \\
\text { fish are not extinct and } \\
\text { resources are appropriately } \\
\text { conserved. }\end{array}$ & - \\
\hline
\end{tabular}




\begin{tabular}{|c|c|c|c|}
\hline \multirow{2}{*}{$\begin{array}{l}\text { The } \\
\text { Achievement } \\
\text { Levels }\end{array}$} & \multicolumn{3}{|c|}{ Decision-Making Aspects } \\
\hline & Stating the Option & $\begin{array}{c}\text { Describing the Decision- } \\
\text { Making Strategy }\end{array}$ & $\begin{array}{c}\text { Weighing the Criteria } \\
\text { According to Personal } \\
\text { Values }\end{array}$ \\
\hline & & (Respondent 71) & \\
\hline $\begin{array}{l}\text { Level } 1 \text { (low- } \\
\text { developed) }\end{array}$ & Action 3. (Respondent 3) & Action 1. (Respondent 106) & $\begin{array}{l}\text { Action 3, because this } \\
\text { action guarantees the } \\
\text { sustainability of the } \\
\text { grouper population in the } \\
\text { future. (Respondent 145) }\end{array}$ \\
\hline
\end{tabular}

Approximately more than a third of the total students, $33.75 \%$ to be precise, only reached the moderate and low-developed level. All decisions at levels 1 and 2 can be classified as non-justificatory arguments that do not have an argumentative force [11]. Table 3 shows that Respondent 82 (level 2) did not provide in-depth judgments. Likewise, Respondent 3 (level 1) only stated the option without giving any consideration. As a result, these decisions are not credible in everyday life.

\subsection{Describing the Decision-Making Strategy}

The environmental SSI in this study has to be considered as a multi-attributes or multi-dimensions problem. Ideally, the chosen option results from integrating multiple attributes obtained through the evaluation process [17]. This process requires a compensatory strategy when all of the advantages and disadvantages compensate one another through tradeoffs [6].

The analysis in this second aspect aimed to map students' decision-making strategies: compensatory or non-compensatory. Achievement on level 3, the high developed category, implies that students can use compensatory strategies in making decisions. The findings showed that only $40.62 \%$ of students used the compensatory strategy. Respondent 9 balanced or compensated the disadvantage of action 3 , the limited stock of grouper fish in the short term, with the advantage of the economic aspect, guaranteed employment opportunities in the fishing industry. Respondent 41 compensated the disadvantage of action 3 with another alternative, specifically the offer to consume other types of fish. The compensatory strategy was also clearly reflected in Respondent 29, who chose action 1 as the best grouper conservation effort. Respondent 29 used the legal aspect to limit grouper exploitation to compensate for the threat of exploitation.

The dominant decision-making strategy used by students in this survey is non-compensatory (level 2). As many as $49.38 \%$ of students only counted on a single attribute and failed to balance alternative solutions' strengths and weaknesses. This strategy can be observed in Respondent 71, who was only concerned with environmental criteria and ignored economic aspects. The results of this study are identical to the findings of several other studies. The initial interview on power plant development's issue (before the intervention or research treatment) conducted by Papadouris et al. [16] indicated that most students constrained themselves to only focusing on sole criteria. The results of the case study conducted by Hong and Chang [12] also concluded that students preferred non-compensatory rules that did not allow trade-offs among alternatives for decisions. These findings triggered researchers to optimize student decision-making strategies through various research innovations.

This survey also revealed that $10.00 \%$ of students (level 1) did not use the decision-making strategy to choose the best solution. The findings on this aspect can be associated with the first aspect's findings, stating the option. Students who do not provide judgment for their chosen option automatically do not provide information on the decision-making strategy used.

\subsection{Weighing the Criteria According to Personal Values}

The analysis of the third aspect of decision-making intended to explore the students' consideration of the relative weight of each criterion. Ideally, students should add higher arithmetic values to more critical and contributive criteria $[13,6]$. 
This study's findings revealed that $96.25 \%$ of students (level 1) could not weigh the criteria according to their values. The rest, $3.75 \%$ of students, achieved a high-developed category (level 3). None of them were at level 2. It infers that most students tend to ignore the complexity of criteria through a noncompensatory and straightforward strategy. They fail to consider trade-offs. For example, Respondent 145 chose action 3 as the final decision based on only one criterion, the grouper population, so there was no effort to weigh many criteria for trade-offs. In contrast, Respondent 19, a high-developed sample on the third aspect, made an order of priority before making a final decision. Respondent 19 explicitly used the weighted criteria phrases: "my priority is . . ." and "I choose action 3 by prioritizing . . .". Meanwhile, Respondent 85 , another high-developed sample, weighed all the criteria equally.

Weighing the criteria is indeed the most challenging aspect of the decision-making process [10], especially for students who have not been exposed to relevant instruction [18]. Papadouris and Constantinou [19] found that grade 6 students failed to weigh the criteria by employing invalid decisionmaking approaches. The study conducted by Seethaler and Lynn [20] revealed that grade 8 students also failed to weigh the trade-offs explicitly on the genetically modified crops issue.

Based on this survey and other empirical findings, it is critical to promote the students' ability to weigh the criteria. Papadouris et al. [16] describes the weighted-additive-value model's abstraction through the concrete optimization strategy proposed below (Figure 1). The optimization strategy also introduces students to the use of arithmetic computation when weighing the criteria of decision making, which consists of the following stages: a) converting data on a standard measurement scale; b) adjusting for the relative importance of the various criteria through the assignment of weighs; c) obtaining overall evaluations for each alternative solution.

\begin{tabular}{|c|c|c|c|}
\hline \multirow{2}{*}{ Which action do you choose? } & & & \\
\hline & Action 1 & Action 2 & Action 3 \\
\hline $\begin{array}{l}\text { The number of groupers } \\
\text { available in the market } \\
\text { shortly }\end{array}$ & High & No offer for three years & Marginal \\
\hline $\begin{array}{l}\text { The number of groupers } \\
\text { available in the market after } \\
\text { three years }\end{array}$ & Sufficient & Sufficient & Sufficient \\
\hline $\begin{array}{l}\text { Threats to } \\
\text { population }\end{array}$ & Overfishing is possible & $\begin{array}{l}\text { Grouper population can } \\
\text { recover completely within } \\
\text { three years }\end{array}$ & Overfishing is not possible \\
\hline $\begin{array}{l}\text { Job opportunities in the } \\
\text { fishing industry }\end{array}$ & $\begin{array}{l}\text { Initially assured, insecure } \\
\text { in case of overfishing }\end{array}$ & Under threat & Assured \\
\hline
\end{tabular}

\section{STEP 1}

Converting data on a standard measurement scale (0-10)

\begin{tabular}{|c|c|c|c|}
\hline & \multicolumn{3}{|c|}{ Score } \\
\hline & Action 1 & Action 2 & Action 3 \\
\hline The number of groupers available in the market shortly & 9 & 5 & 7 \\
\hline The number of groupers available in the market after three years & 10 & 10 & 10 \\
\hline Threats to grouper population & 0 & 8 & 10 \\
\hline Job opportunities in the fishing industry & 6 & 5 & 10 \\
\hline
\end{tabular}

\section{STEP 2}

Assigning weighs (on a scale from 1 to 10) to adjust for the relative importance of criteria

\begin{tabular}{|c|c|c|c|c|}
\hline & \multirow{2}{*}{ Weigh } & \multicolumn{3}{|c|}{ Score } \\
\hline & & Action 1 & Action 2 & Action 3 \\
\hline $\begin{array}{l}\text { The number of groupers available in the market } \\
\text { shortly }\end{array}$ & 8 & 9 & 5 & 7 \\
\hline $\begin{array}{l}\text { The number of groupers available in the market } \\
\text { after three years }\end{array}$ & 7 & 10 & 10 & 10 \\
\hline Threats to grouper population & 10 & 0 & 8 & 10 \\
\hline Job opportunities in the fishing industry & 9 & 6 & 5 & 10 \\
\hline
\end{tabular}

STEP 3

Obtaining an overall evaluation 


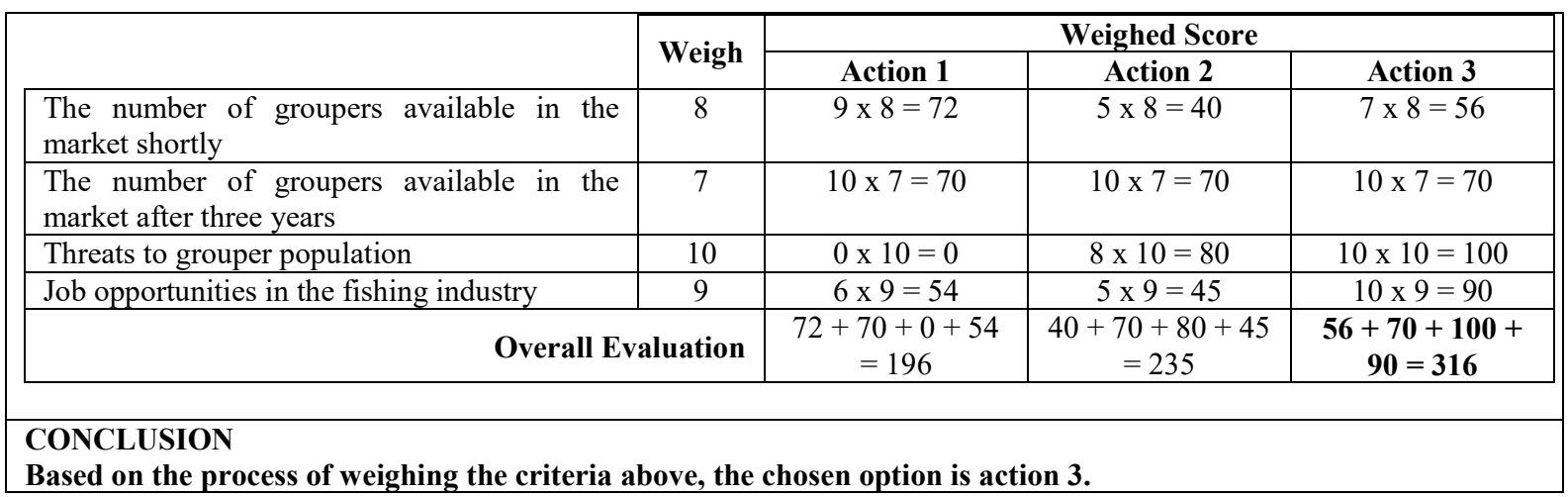

Figure 1 An example of the optimization strategy in the future of grouper fish's issu

\section{CONCLUSION}

The present study showed that students' decisionmaking abilities vary in every aspect. The ability to state the option of most students was high-developed. Students' mastery of describing the decision-making strategy was mostly moderate-developed. Meanwhile, the ability to weigh the criteria according to most students' values was still low-developed. Henceforth, researchers are expected to consider these findings in formulating scientific learning innovations oriented towards decision-making optimization strategy to support the SDGs' achievement.

\section{ACKNOWLEDGMENTS}

This paper's preparation was supported by the Indonesian Endowment Fund for Education (LPDP) under Beasiswa Pendidikan Indonesia-Dalam Negeri 2018 (Number: KET-462/LPDP.3/2019). We also sincerely thank Dra. Sri Kismiyati, Rini Sumiasri, S.Pd, and Siti Rochmah, M.Eng, for the help in the data collection process.

\section{REFERENCES}

[1] Ministry of National Development Planning, Roadmap of SDGs Indonesia: A Highlight, Secretariat for Sustainable Development Goals, 2019.

[2] X. Zhou, M. Moinuddin, Sustainable Development Goals Interlinkages and Network Analysis: A Practical Tool for SDG Integration and Policy Coherence, Institute for Global Environmental Strategies, 2017.

[3] UNESCO, Aichi-Nagoya Declaration on Education for Sustainable Development, United Nations, 2014.
[4] C. Garrecht, T. Bruckermann, U. Harms, Students' Decision-Making in Education for Sustainability-Related Extracurricular Activities: A Systematic Review of Empirical Studies, Sustainability 10(11) (2018) 3876-3895. DOI: https://doi.org/10.3390/su10113876

[5] S. Boehmer-Christiansen, The Geo-Politics of Sustainable Development: Bureaucracies and Politicians in Search of the Holy Grail, Geoforum 33(3) (2002) 351-365. DOI: https://doi.org/10.1016/S0016-7185(02)00018-0

[6] H. Gresch, M. Hasselhorn, S. Bögeholz, Enhancing Decision-Making in STSE Education by Inducing Reflection and Self-Regulated Learning, Research in Science Education 47 (2017) 95-118. DOI: https://doi.org/10.1007/s11165-015-9491-9

[7] H. Meyer, Teachers' Thoughts on Student Decision Making During Engineering Design Lessons, Education Sciences 8(1) (2018) 9-20. DOI: https://doi.org/10.3390/educsci8010009

[8] A. Mettas, The Development of DecisionMaking Skills, EURASIA Journal of Mathematics, Science and Technology Education 7(1) (2011) 63-73. DOI: https://doi.org/10.12973/ejmste/75180

[9] H. Gresch, S. Bögeholz, Identifying NonSustainable Courses of Action: A Prerequisite for Decision-Making in Education for Sustainable Development, Research in Science Education 43 (2013) 733-754. DOI: https://doi.org/10.1007/s11165-012-9287-0

[10] S. Eggert, S. Bögeholz, Students' Use of Decision-Making Strategies with Regard to Socioscientific Issues: An Application of the Rasch Partial Credit Model, Science Education 
94(2) (2009) 230-258. DOI: https://doi.org/10.1002/sce.20358

[11] J.M. Dauer, M. Lute, O. Straka, Indicators of Informal and Formal Decision-making about a Socioscientific Issue, International Journal of Education in Mathematics, Science and Technology 5(2) (2017) 124-138. DOI: https://doi.org/10.18404/ijemst.05787

[12] J-L. Hong, N-K. Chang, Analysis of Korean High School Students' Decision-Making Processes in Solving a Problem Involving Biological Knowledge, Research in Science Education 34 (2004) 97-111. DOI: https://doi.org/10.1023/B:RISE.0000020884.522 $\underline{40.2 \mathrm{~d}}$

[13] C. Nicolaou, K. Korfiatis, M. Evagorou, C. Constantinou, Development of Decision-Making Skills and Environmental Concern through Computer-Based, Scaffolded Learning Activities, Environmental Education Research 15(1) (2009) 39-54. DOI: https://doi.org/10.1080/13504620802567007

[14] M.S. Topcu, T.D. Sadler, O. Yilmaz-Tuzun, Preservice Science Teachers' Informal Reasoning about Socioscientific Issues: The Influence of Issue Context, International Journal of Science Education 32(18) (2010) 2475-2495. DOI:

https://doi.org/10.1080/09500690903524779

[15] T.D. Sadler, S. Barab, B. Scott, What Do Students Gain by Engaging in Socioscientific Inquiry? 37 (2007) 371-391. DOI: https://doi.org/10.1007/s11165-006-9030-9

[16] N. Papadouris, D. Papademetriou, T. Kyratsi, C. Constantinou, Developing Research-Based Technology-Enhanced Curriculum Materials: An Example in the Context of Decision-Making Skills, in: Z.C. Zacharia, C.P. Constantinou (Eds.), Proceedings of the 7th Computer-Based Learning in Science Conference, University of Zilina, 2005, pp. 342-353.

[17] F. Böttcher, A. Meiser, Effects of Direct and Indirect Instruction on Fostering DecisionMaking Competence in Socioscientific Issues, Research in Science Education 43 (2013) 479506. DOI: https://doi.org/10.1007/s11165-011$\underline{9271-0}$

[18] N. Papadouris, Optimization as a Reasoning Strategy for Dealing with Socioscientific
Decision-Making Situations, Science Education 96(4) (2012) 600-630. DOI: https://doi.org/10.1002/sce.21016

[19] N. Papadouris, C. Constantinou, Approaches Employed by Sixth-Graders to Compare Rival Solutions in Socio-Scientific Decision-Making Tasks, Learning and Instruction 20(3) (2010) pp. 225-238.

DOI: https://doi.org/10.1016/j.learninstruc.2009.02.02 $\underline{2}$

[20] S. Seethaler, M. Linn, Genetically Modified Food in Perspective: An Inquiry-Based Curriculum to Help Middle School Students Make Sense of Tradeoffs, International Journal of Science Education 26(14) (2004) 1765-1785. DOI: https://doi.org/10.1080/09500690410001673784 